\title{
Assessment of Water Suitability for Irrigation in Keffi, Nasarawa State, Nigeria
}

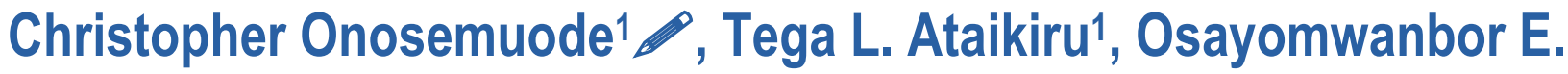 Oghama ${ }^{1}$}

${ }^{1}$ Department of Environmental Science, College of Science, Federal University of Petroleum Resources, Effurun, Delta State.

\begin{abstract}
The assessment of water quality for irrigation was carried out on the Antau river and surrounding wells in Keffi. Samples were collected along the river course; $150 \mathrm{~m}$ apart using standard methods and at five different points using the grab technique. Also, samples were collected from wells in the study area. The colorimetric and titrimetric methods were used for water sample analysis. These methods were used to determine the presence of several elements in the different water samples used for agricultural purposes. Electrical conductivity, $\mathrm{pH}$, nitrate, boron, temperature, total nitrogen, sulphate, sodium adsorption ratio (SAR) and adjusted sodium adsorption ratio (Adj. SAR) were determined for the samples. The values of the parameters were compared with recommended standards. A comparative analysis was carried out between river and well water. The high value of total dissolved solids and electrical conductivity were indications of the presence of high amount of salts in water. Bicarbonates concentration was low in the study area with mean values of 0.6075 and 0.0153 for river Antau and wells, respectively. Low values of $0.0054-0.0283$ (Antau river) and $0.0216-1.4257$ (well) of boron were obtained in this study. The water from the Antau River and wells were classified using sodium adsorption ratio (SAR) and electrical conductivity as stated by salinity hazards United States Department of Agriculture (USDA) as bad, marginal, moderate and good water. On the whole, well water was better than the Antau River but both sources of water can be used for agricultural purposes.
\end{abstract}

Keywords: Irrigation, Water, Sodium Adsorption Ratio, Suitability

\section{INTRODUCTION}

About $85 \%$ of Africa's poor living in rural areas depends mainly on agriculture for their livelihood. Agricultural growth is a major key to rural poverty alleviation and contributes to achieving millennium development goal (Rosegrant et al., 2005). Despite, the insufficient rainfall and a high incidence of droughts, food production in Africa is entirely rain fed (FAOSTAT, 2009). An adequate water supply is required for plant growth. When rainfall is not sufficient, it is necessary to supply water through irrigation. Irrigation is the artificial application of water to the soil with a view of raising plants through interaction in the soil - plant system (Allen et al., 2006; You et al., 2010). Different methods are used to supply water to the plants. Every method has its advantages and disadvantages and any method adopted should best suit the local circumstances. A simple method is to bring water from a source e.g. well or stream to each plant with a bucket or watering can. However, surface and internal soil drainage problem arise, even in the areas where irrigation water is limited; these problems are attributed largely to lack of proper farm water management (Chartres and Varma, 2010). These are more evident in the developing countries where irrigation and drainage practices are used as means of putting more land into raising more food for the rapidly increasing population (You et al., 2010). However, there are countries where the level of water management efficiency is very low and studies have shown that $58 \%$ of the rural population in Sub-Sahara could benefit from some type of investment in water (Faures and Santini, 2008). The problems of poor water management often lead to serious consequences on the soil partly as a result of excessive irrigation, low soil water infiltration and permeability rates, such problems include soil moisture retention, characteristics development of an impermeable soil layer near the surface among others (Fischer et al., 2001).

This article is published under the terms of the Creative Commons Attribution License 4.0

Author(s) retain the copyright of this article. Publication rights with Alkhaer Publications.

Published at: http://www.ijsciences.com/pub/issue/2016-07/

DOI: 10.18483/ijSci.998; Online ISSN: 2305-3925; Print ISSN: 2410-4477 
The assessment of water quality for irrigation will require the determination of salinity, sodicity, toxicity and bicarbonate concentration (Schafer, 1983; Allen et al., 2006). Although, concern about water quality for irrigation and the criteria as well as the standard for its assessment are known in different parts of the world. Many areas of the world especially where irrigation is practiced, there is yet to be a functional and reputable system of irrigation (You et al., 2010).

The study area covers the banks of River Antau in Keffi, Nasarawa State; where irrigation practices are carried out using the stream water. The stream collects the domestic wastes of household living along the river banks and industrial effluent; drain them into River Uke, which links with the River Antau. Farmers use the water for irrigation purposes without any form of treatment, hence the need for this study with the aim of evaluating the level of its suitability for irrigation purpose.

A number of studies have shown that there is increase in crop yields as a result of using sewage and industrial effluent for irrigation (Pescot, 1992). However, the suitability of irrigation water needs to be evaluated on the basis of the specific condition under which it will be used. It is against this backdrop that this study is aimed at determining some chemical compositions of the water in River Antau to ascertain its suitability for irrigation purpose.

\section{MATERIALS AND METHODS Water Sampling Procedure}

The sampling of water along the River course was done at interval of $150 \mathrm{~m}$ apart. Five sampling points were identified along the River course beginning with the point where the river entered the study area; another point was identified at Mayanka drain, mid river, after the mid river and the last point was at Federal Government College (FGC). Samples were collected at each of these points along the River using the grab techniques and the sampling container was submerged to about $15 \mathrm{~cm}$ beneath the surface level of the flowing water and inclined against the direction of flow.

The well sampled were from the following quarters in the study area that are close to where irrigated farming was carried out namely; Sabon Pegi, Kofar Gonya, Angwan Mada, Kofar Hausa and Kofar Masa. The collection of samples was undertaken manually using $1-2$ liter sterile plastic containers. The sample for each point was properly labeled for easy identification. The sampling procedure was carried out according to APHA (2008), which among other things; states that the containers must be cleansed, rinsed with distilled water and covered after drying to avoid or minimize contamination with foreign materials.

\section{LABORATORY ANALYSIS \\ Water Sample Analysis}

The atomic absorption, flame emission, colorimetric and titrimetric methods were used. These methods were used to determine the presence of several elements in the different sources of water used for agricultural purposes. A recommended procedure is to transfer a $500 \mathrm{ml}$ aliquot of the water sample into an evaporating dish and add $15 \mathrm{ml}$ of concentrated $\mathrm{HNO}_{3}$, evaporate on a steam bath to approximately $25 \mathrm{ml}$, transfer to a $50 \mathrm{ml}$ acid wash volumetric flask and bring to volume with distilled water (APHA, 2008).

\section{Method used for the Parameters.}

The following parameters were tested in order to evaluate water quality for irrigation. These include:

i. Total salts (Electrical conductivity)

ii. Acidity or alkalinity $(\mathrm{pH})$

iii. Constituent

Cation: Calcium (Ca), Magnesium ( $\mathrm{Mg}$ ), Sodium (Na) and Potassium (K).

Anion: Bicarbonate $\left(\mathrm{HCO}_{3}\right)$, Sulphate $\left(\mathrm{SO}_{4}\right)$, Chloride $(\mathrm{Cl})$, Carbonate $\left(\mathrm{CO}_{3}\right)$ and Nitrate $\left(\mathrm{NO}_{3}\right)$.

iv. Trace element: Boron (B)

Specifically, the parameters were determined as set out below:

\section{i. Cations constituents}

Analysis for sodium $(\mathrm{Na})$ and potassium $(\mathrm{K})$ was by flame photometry, while calcium (Ca) and magnesium $(\mathrm{Mg})$ were by atomic absorption spectrophotometry.

\section{ii. Soluble Anions}

The anions were determined by various colorimetric and titrimetric methods.

\section{iii. Carbonates and Bicarbonates}

The carbonates and bicarbonates were determined by combined rapid titration method with $0.05 \mathrm{~N}$ sulphuric acid, using phenolphthalein and methyl red as indicator.

iv. Chloride

Chloride was measured, using chloride meter, which automatically titrates the chloride against silver ions.

$\begin{array}{ll}\text { v. Sulphate } & \\ \text { The sulphate content was determined }\end{array}$ turbidimetrically.

vi. Total Nitrogen

Total Nitrogen was analyzed by the modified macro kjeldahl distillation method in which ammonium and nitrate nitrogen was determined together.

vii. Boron 
Total Boron was determined by the Azomethine $-\mathrm{H}$ extraction procedure (Malgwi, 2000). Boron was extracted, using sodium acetate. Based on Azomethine $-\mathrm{H}$, when a yellowish orange colour developed, the concentration was read using a spectrophotometer.

viii. Electric Conductivity (EC)

The total concentration of salts was determined by using the conductivity meter.

ix. $\quad$ Acidity and Alkalinity $(\mathrm{pH})$

The $\mathrm{pH}$ value was measured using a digital pH meter, with a glass electrode.

xi. Water Temperature

The Laboratory room temperature was measured. The thermometer was held with one hand and about half $(1 / 2)$ of it dipped into the water for some minutes, brought out and the reading was taken and recorded in degrees Celsius.

ix. Sodium Adsorption Ratio (SAR) and Adjusted Sodium Adsorption Ratio

(Adj. SAR)

These were determined, using the following equations and relationship (Malgwi, 2000).

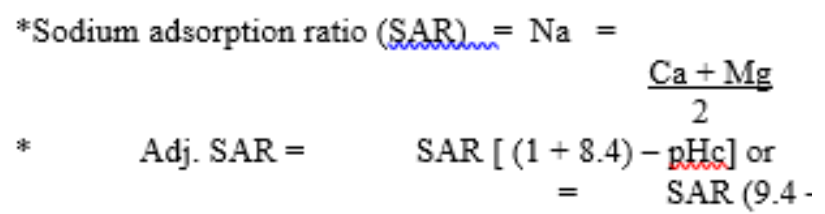

Where:

$$
\begin{aligned}
& \mathrm{pHc} \quad=\mathrm{pK}_{2}-\mathrm{pK}_{6}+\mathrm{p}(\mathrm{Ca}+\mathrm{Mg})+\mathrm{p}\left(\mathrm{HCO}_{3}\right) \\
& \mathrm{pK}_{2}-\mathrm{pKc}=\mathrm{p}\left(\mathrm{Ca}_{\mathrm{a}}+\mathrm{mg}+\mathrm{Na}\right) \\
& \mathrm{p}\left(\mathrm{HCO}_{3}\right)=\mathrm{p}\left(\mathrm{CO}_{3}+\mathrm{HCO}_{3}\right)
\end{aligned}
$$$$
\text { * } \quad \mathrm{ESP}=
$$$$
\frac{\mathrm{Na} \times 100}{\mathrm{Ca}+\mathrm{Mg}+\mathrm{K}+\mathrm{Na}}
$$

Where concentrations are in milliequivalent per liters of the respective ions.

\section{ASSESSMENT METHOD}

The values of parameters determined for this study were compared with standards recommended for irrigation water (Ayers and Westcot 1985; London, 1991 and USDA, 2003). A comparative analysis was also carried out between River Antau water and the well water to determine whether or not the well, water is better than the river water in quality.

\section{DISCUSSION OF RESULTS}

\section{Assessment of Water Suitability for Irrigation}

To assess the suitability of irrigation water for agriculture other factors must be considered besides water quality. These include salt tolerance of the crop being cultivated and the characteristics of the soil under irrigation, climate, soil and water management practices among others as they have impact on the extent of water quality (http://www.irrigation.org/default.aspx). However, this study has not included plants. It is assumed that the suitability of water for irrigation must be determined by the cropping problems that can be developed with poor water quality. The problems that result from using poor water quality according to Allen et al., (2006), vary in kind and degree. In this study, we adopted the common criteria of salinity hazards and toxicity hazards of the U.S Salinity laboratory staff, 2003; London, 1991; Ayers and Westcot, 1985 Guidelines for Interpretation of Water quality for Irrigation. The details of analyzed samples for both river and well water are shown in Appendices 1 and 2, respectively.

\section{ASSESSING WATER SALINITY FOR IRRIGATION}

Tables 1 and 2 show high levels of total dissolved solids and electrical conductivity in the samples of water from River Antau and well water as compared to the guidelines for interpretation of water quality (Table 3). The high level of total dissolved solids and electrical conductivity are indications of the presence of high amount of salts in the waters.

Table 1: Concentration of Total Dissolved Solids and Electrical Conductivity in River Antau

\begin{tabular}{|l|l|l|}
\hline Sampling Sites & Total Dissolved Solid Mg/l & $\begin{array}{l}\text { Electrical } \\
\text { Micromhos/cm }\end{array}$ \\
\hline Water sample before river antau & 249 & 21.02 \\
\hline Water sample at mayanka drain & 544 & 20.06 \\
\hline Water sample at mid river & 430 & 14.53 \\
\hline Water sample after mid river & 357 & 9.24 \\
\hline Water sample at FGC & 612 & 18.25 \\
\hline
\end{tabular}

Source: Field and Laboratory Analysis, 2014 
Table 2: Concentration of Total Dissolved Solids and Electrical Conductivity in Well Water

\begin{tabular}{|l|l|l|}
\hline Sampling Sites & Total Dissolved Solid Mg/l & $\begin{array}{l}\text { Electrical } \\
\text { Micromhos/cm }\end{array}$ \\
\hline Sabon Pegi & 217 & 21.02 \\
\hline Kofar Goriya & 480 & 14.22 \\
\hline Angwan Mada & 650 & 12.26 \\
\hline Kofar Hausa & 457 & 8.74 \\
\hline Kofar Masa & 312 & 16.23 \\
\hline
\end{tabular}

Source: Field and Laboratory Analysis, 2014

Table 3: Guidelines for Interpretation of Water quality for Irrigation

\begin{tabular}{|l|l|l|l|}
\hline Water Quality & \multicolumn{1}{|c|}{ Degree of Problems } & Severe \\
\hline Criterion & None & Increasing & $>3.0$ \\
\hline Salinity: & $<0.75$ & $0.75-3.0$ & \\
\hline EC(mmhos/cm) & \multicolumn{2}{|l|}{} \\
\hline Specific Ion Toxicity: & $<3$ & $3-9$ & $>9$ \\
\hline Sodium Adj: SAR & $<4$ & $4-10$ & $>10$ \\
\hline Chloride (meq/L) & $<0.75$ & $0.75-2.0$ & $>2.0$ \\
\hline Baron (meq/L or ppm) & \multicolumn{2}{|l|}{} \\
\hline Miscellaneous Effects: & $<5$ & $5-30$ & $>30$ \\
\hline Nitrates (meq/L) & $1.5-8.5$ & $>8.5$ \\
\hline Bicarbonates (meq/L) & $<1.5$ & \\
\hline Ph & Normal range 6.5-8.4 & \\
\hline
\end{tabular}

Source: Ayers and Westcot, 1985

The direct effect of salinity is that it restricts the availability of soil water to plant a scenario responsible for the depletion in crop physiology and yield. High amount of salts in irrigation water will affect the plants osmotic activity. This will reduce the uptake of water and nutrients from the soil thus, interfering with the normal crop growth and productivity. The high content of salt shown in the River and well water may likely inhibit crop production in the study area.

\section{ASSESSING WATER SODICITY FOR IRRIGATION}

The effects of sodium depend on the amount of other cations in water and this is related to its percentage to other cations and sodium adsorption ratio (SAR). Tables 4 and 5 give sodium percent and sodium adsorption ratio of River Antua and well water in the study area.

Table 4: Sodium Percentage and Adsorption Ratio of River Antau

\begin{tabular}{|l|l|l|}
\hline Sampling Sites & Sodium Percentage & SAR \\
\hline Water sample before river Antau & 1.17 & 26.36 \\
\hline Water sample at Mayanka drain & 0.75 & 0.23 \\
\hline Water sample at Mid river & 0.25 & 9.88 \\
\hline Water sample after Mid river & 0.26 & 0.24 \\
\hline Water sample at FGC & 0.13 & 0.01 \\
\hline
\end{tabular}

Source: Field and Laboratory Analysis

Table 5: Sodium Percentage and Adsorption Ratio of Well Water

\begin{tabular}{|l|l|l|}
\hline Sampling Sites & Sodium Percent & SAR \\
\hline Sabon Pegi & 0.44 & 0.53 \\
\hline Kofar Goriya & 0.32 & 0.02 \\
\hline Angwan Mada & 0.05 & 0.01 \\
\hline Kofar Hausa & 2.21 & 2.92 \\
\hline Kofar Masa & 0.34 & 0.13 \\
\hline
\end{tabular}

Source: Field and Laboratory Analysis 
The result for Antau River shows the value of sodium percentage range of between 0.13 and 1.17 and the range for well water is between 0.05 and 2.21. Values of sodium below $60 \%$ or 0.6 are considered satisfactory for irrigation for most soils (Fipps, 2003). With the permissible value of $60 \%$ or 0.6 as put forward by Fipps (2003), River water at mid river, after mid river and at FGC are satisfactory for irrigation while that before the Antau river and at Mayanka drain are not satisfactory for irrigation. For the well water, all the wells sampled except that at Kofar Hausa are satisfactory for irrigation purpose.

The SAR of the River water ranged between 0.01 and 26.36 with an average of 7.3447 (Table 4 and Appendix 1) while, that of the well water ranged between 0.01 and 2.92 with an average of 0.7218 (Table 5 and Appendix 2). The SAR of both River Antau water and well water are considered good for irrigation. River Antau water is giving its degree of problem to be increasing due to the facts that its mean value is 7.3447 while that of the ground water will be good without any problem.

\section{ASSESSING WATER TOXICITY FOR IRRIGATION}

Specific constituents of irrigation water, such as boron $(\mathrm{B})$, chloride $(\mathrm{Cl})$ and sodium $(\mathrm{Na})$, are potentially toxic to crops (Bolen, 2002). In the FAO system (London, 1991), the toxicity is appraised as follows. Sodium $(\mathrm{Na}+)$ toxicity diagnosed by the SAR parameters, chloride $(\mathrm{Cl})$ toxicity diagnosed by the Chloride concentration.
Trace elements might be in minute concentration in irrigation water but may be toxic to most plants. However, most plants require small amount of these specific ionic elements such as boron and bicarbonates. Boron concentration is generally low ranging from 0.0054 to 0.0283 with a mean value of 0.0153 (Appendix 1) for River Antau and from 0.0216 to 1.4257 with a mean value of 0.6075 (Appendix 2) for well water. Boron in most water hardly exceeds 2mg/l (Ayers and Westcot, 1985; Fipps, 2003). These low values of boron observed in the study area implied that the concentration of boron does not pose problems for both soil and plants.

Bicarbonates concentration is also generally low in the study area as its mean concentration is 0.6075 and 0.0153 for River Antau and well waters, respectively. Water with low bicarbonates as observed in the study area, will not result in the precipitation of calcium and magnesium ions from the soil thereby enhancing their effectiveness in counteracting sodicity hazards.

\section{CLASSIFICATION OF IRRIGATION WATER QUALITY FOR THE STUDY AREA}

Using sodium adsorption ratio and electrical conductivity of both River Antau and well water, a classification of water for irrigation purpose is presented in Tables 6 and 7 using the classification of irrigation waters with regard to sodium and salinity hazards of USDA, 2003 (Figure 1). The classification of water for River Antau shows that the water before River Antau is bad (Table 6). The limitation in its use for irrigation is the high amount of total salts as indicated by the high sodium adsorption ratio recorded.

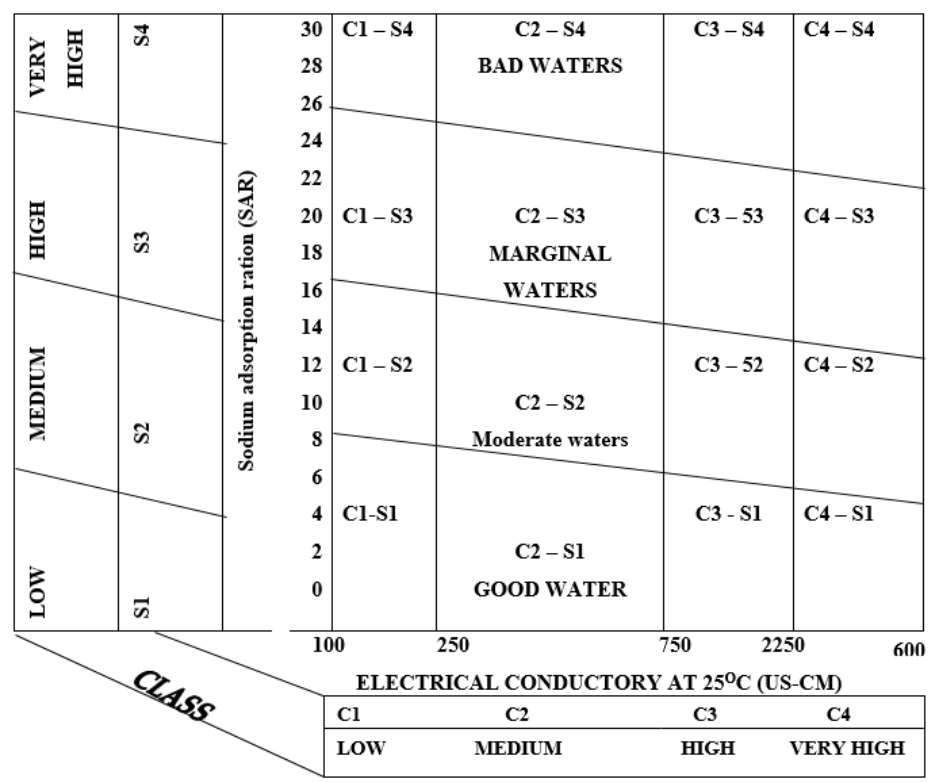

Figure 1: Classification of irrigation waters with regards to sodium and salinity hazards (USDA, 2003) 
This may be due to the high level of human activities close to the bank of the river which ranged from the use of the river as refuse disposal point, bathing among other activities. The use of water at the site before Antau River calls for the observation and maintenance of water quality standards for irrigation and the selection of tolerant crops.
The water at the mid river is considered moderate while other sites are rated good for irrigation purposes. The classification of well water as shown in Table 7 indicated that water from the wells were certified good for irrigation purpose and pose no threat to crop production in the study area.

Table 6: Classification of Water quality for River Antau

\begin{tabular}{|l|l|l|l|l|}
\hline Sampling Sites & EC (Micromhos/cm) & SAR & Classification & Remark \\
\hline $\begin{array}{l}\text { Water sample before } \\
\text { River Antau }\end{array}$ & 21.0 & 26.36 & CIS4 & Bad water \\
\hline $\begin{array}{l}\text { Water sample at } \\
\text { Mayanka drain }\end{array}$ & 20.06 & 0.23 & C1S1 & Good water \\
\hline $\begin{array}{l}\text { Water sample at mid } \\
\text { river }\end{array}$ & 14.53 & 9.88 & C1S2 & Moderate water \\
\hline $\begin{array}{l}\text { Water sample after } \\
\text { mid river }\end{array}$ & 9.24 & 0.24 & C1S1 & Good water \\
\hline Water sample at FGC & 18.25 & 0.01 & C1S1 & Good water \\
\hline
\end{tabular}

Source: Field and Laboratory Analysis, 2014

Table 7: Classification of water Quality for Well Water

\begin{tabular}{|l|l|l|l|l|}
\hline Sampling Sites & EC $($ Micromhos/cm) & SAR & Classification & Remark \\
\hline Sabon Pegi & 21.02 & 0.53 & CIS1 & Good water \\
\hline Kofar Goriya & 14.22 & 0.02 & C1S1 & Good water \\
\hline Angwan Mada & 12.26 & 0.01 & CIS1 & Good water \\
\hline Kofar Hausa & 8.74 & 2.91 & C1S1 & Good water \\
\hline Kofar Masa & 16.23 & 0.13 & C1S1 & Good water \\
\hline
\end{tabular}

Source: Field and Laboratory Analysis, 2014

The chemical characteristics of the underground water (well) and surface (river) water were presented and assessed according to the criteria of salinity, toxicity and sodicity in order to evaluate their qualities for irrigation as stated earlier. The values of the parameters for the River water were compared with those of well water to determine whether or not the well water is better than the river water in quality. It was observed that, salinity; sodicity and toxicity levels from both sources are not a major threat to irrigation on the Keffi plain. The quality of under-ground water is generally stable of surface water however, varies throughout the year as the rate of flow varies (Grattan, 2004). In this study, well water proves to be better than river water in quality. The values obtained for well water were within the range of excellent to good water, while some of the values of river water were within the permissible range. On the whole, both water from the river and well are suitable for irrigation purposes based on their mean values of parameters.

\section{CONCLUSION}

Water used for irrigation varies greatly in quality depending on type and quantity of dissolved salts that are present in relatively small but significant amounts. Water quality or suitability for use is judged on the potential severity of problems they may pose after long-term use. From this study, the implication of the findings of both well and river water quality showed that they are suitable for irrigation purposes while the soils in the study area can be classified as "Saline-sodic and may not be good as they contain sufficient amount of soluble salts to interfere with germination, growth and yield of most crop plants.

\section{REFERENCES}

1) Allen, R. G., Pereira, L. S., Raes, D. and Smith, M. 2006 Guidelines for computing crop water requirements. Food and Agriculture Organization Irrigation and Drainage 56: 171177.

2) American Public Health Association (APHA). 2008. Standard Methods for the Examination of Water and Wastewater. $21^{\text {st }}$ ed. Washington, DC.

3) Ayers, R. S. and Westcot, D. W. 1985. Water quality for agriculture. Irrigation And Drainage Paper 29. Food and Agriculture Organization of the United Nations, Rome. 174 pp.

4) Chartres, C. and Varma, S. 2010. Out of water. From Abundance to Scarcity and How to Solve the Water Problems. FT Press, United States of America.

5) Faures, J. M. and Santini, G. 2008. Water and the Rural Poor: Interventions for Improving Livelihoods in SubSaharan Africa. Rome Food and Agriculture Organization. 
6) Fipps, G. 2003. Irrigation Water Quality Standards and Salinity Management Strategies. Texas A\&M University System, College Station, Texas. 20pp. http://itc.tamu.edu/documents/extensionpubs/B-1667.pdf

7) Fischer, G., Shah, M., Velthuizen, H. and Nachtergaele, F. 2001. Global Agro-Ecological Assessment for Agriculture in the $21^{\text {st }}$ Century. International Institute for Applied Systems Analysis. Laxenburg, Austria.

8) Food and Agriculture Organization Aquastat (FAOSTAT), 2009.

http://www.fao.org/nr/water/aquastat/dbase/index.stm.

9) Grattan, S. R., Grieve, C. M., Poss, J. A., Robinson, J. H., Suarez, D. L. and Benes, S. E. 2004. Evaluation of salt tolerant forages for sequential water reuse systems. Implications for ruminant mineral nutrition. Agriculture Water Management. 70:137-150.

10) Pescod, M. B. 1992. Waste Water Treatment and Use in Agriculture. Food and Agriculture Organization (FAO) Irrigation and Drainage. 47.

11) Rosegrant, M. W., Ringler, C., Benson, T., Diao, X., Resnick, D., Thurlow, J., Torero, M. and Orden, D. 2006.
Agriculture and Achieving the Millennium Development Goals Washington, D.C.

12) Schafer, W. M. 1983. Irrigation Water Quality in Montana. Montana State University, Co- operative Extension Services. Montguide, MT8373.

13) Synder, R. L. and Melo-Abreu, J. P. 2005. Frost Protection: Fundamentals, Practices and Economics. Food and Agriculture Organization of the United Nations. ISSN 1684 8241.

14) You, L., Ringler, C., Nelson, G., Wood-Sichra, U., Robertson, R. Wood, S., Guo, Z., Zhu, T and Sun, Y. 2010. What Is the Irrigation Potential for Africa? A combined biophysical and socioeconomic Approach. IFPRI Discussion Paper 00993. http://www.ifpri.org/publications/results/taxonomy\%3A468.

15) Malgwi, W. B., Ojanuga, A. G., Chude, V. O., Kparmwang, T. and Raji, B. A. 2000. Morphorlogical and physical properties of some soils of Samaru, Zaria. Nigerian Journal of Soil Research. 1:58-64.

16) London, J. R. 1991. Booker Tropical Soil Manual Longman Scientific and Technical. Booker Tate, New York, U.S.A. 
APPENDIX 1: RIVER ANTAU WATER CHARACTERISTICS (CHEMICAL PROPERTIES)

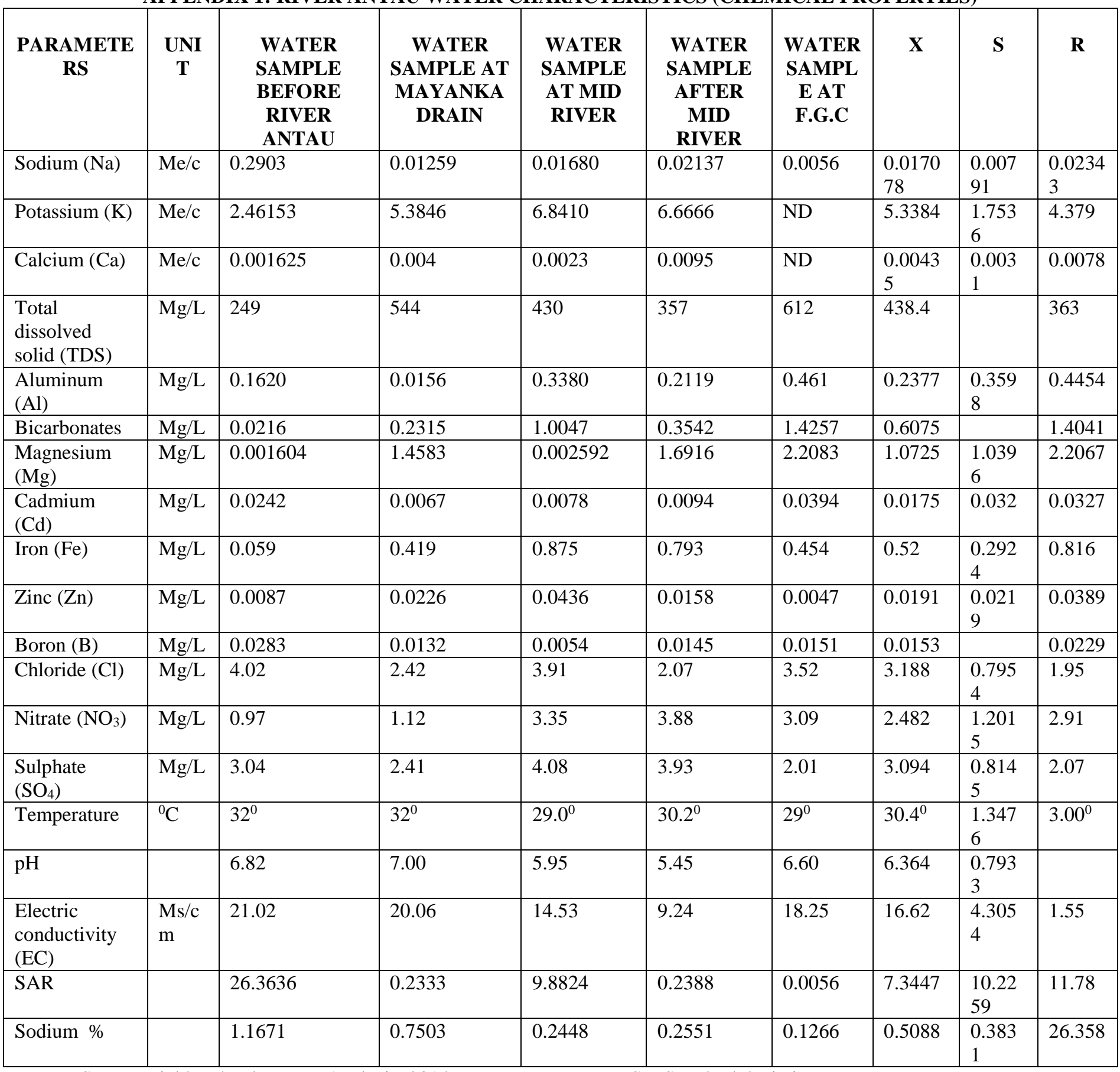


Assessment of Water Suitability for Irrigation in Keffi, Nasarawa State, Nigeria

APPENDIX 2: GROUND WATER (WELL WATER) CHARACTERISTICS CHEMICAL PROPERTIES

\begin{tabular}{|c|c|c|c|c|c|c|c|c|c|}
\hline PARAMETERS & UNIT & $\begin{array}{c}\text { SABON } \\
\text { PEGI }\end{array}$ & $\begin{array}{l}\text { KOFAR } \\
\text { GORIYA }\end{array}$ & $\begin{array}{c}\text { ANGWAN } \\
\text { MADA }\end{array}$ & $\begin{array}{l}\text { KOFAR } \\
\text { HAUSA }\end{array}$ & $\begin{array}{c}\text { KOFAR } \\
\text { MASA }\end{array}$ & $\mathbf{X}$ & $\mathbf{S}$ & $\mathbf{R}$ \\
\hline Sodium $(\mathrm{Na})$ & $\mathrm{Me} / \mathrm{c}$ & 0.0257 & 0.002316 & 0.0306 & 0.0376 & 0.4521 & 0.11582 & 0.1905 & 0.4387 \\
\hline Potassium $(\mathrm{K})$ & $\mathrm{Me} / \mathrm{c}$ & 4.5897 & ND & ND & ND & ND & 4.5897 & 0.0000 & 4.5897 \\
\hline Calcium $(\mathrm{Ca})$ & $\mathrm{Me} / \mathrm{c}$ & 0.0039 & ND & 0.0015 & 0.002 & 0.318 & 0.0809 & 0.1369 & 0.3178 \\
\hline $\begin{array}{l}\text { Total Dissolved } \\
\text { Solid }\end{array}$ & $\mathrm{Mg} / \mathrm{L}$ & 217 & 480 & 650 & 457 & 312 & 423.2 & & 433 \\
\hline Aluminum (Al) & $\mathrm{Mg} / \mathrm{L}$ & 0.1620 & 0.1300 & 0.0113 & 0.0380 & 0.2160 & 0.1114 & 0.2636 & 0.2047 \\
\hline Bicarbonates & $\mathrm{Mg} / \mathrm{L}$ & 0.0151 & 0.0054 & 0.0132 & 0.0145 & 0.0283 & 0.0153 & & 0.0229 \\
\hline Magnesium (Mg) & $\mathrm{Mg} / \mathrm{L}$ & 1.1979 & 7.3333 & 0.0003 & 1.6666 & 0.0014 & 2.0399 & 1.4551 & 7.333 \\
\hline Cadmium $(\mathrm{Cd})$ & $\mathrm{Mg} / \mathrm{L}$ & 0.0242 & 0.263 & 0.0350 & 0.0357 & 0.0129 & 0.0754 & 0.0963 & 0.2501 \\
\hline Iron $(\mathrm{Fe})$ & $\mathrm{Mg} / \mathrm{L}$ & 0.059 & 0.267 & 0.481 & 0.175 & 0.062 & 0.2088 & 0.1566 & 0.422 \\
\hline Zinc $(\mathrm{Zn})$ & $\mathrm{Mg} / \mathrm{L}$ & 0.0087 & 0.0243 & 0.0185 & 0.0208 & 0.0282 & 0.0201 & 0.0087 & 0.0195 \\
\hline Boron $(\mathrm{B})$ & $\mathrm{Mg} / \mathrm{L}$ & 1.0047 & 0.2315 & 0.0216 & 0.3542 & 1.4257 & 0.6075 & & 1.4041 \\
\hline Chloride $(\mathrm{Cl})$ & $\mathrm{Mg} / \mathrm{L}$ & 4.62 & 3.00 & 1.72 & 2.10 & 2.76 & 2.84 & 0.8033 & 2.3 \\
\hline Nitrate $\left(\mathrm{NO}_{3}\right)$ & $\mathrm{Mg} / \mathrm{L}$ & 0.97 & 1.93 & 2.32 & 4.21 & 2.86 & 2.458 & 1.0724 & 3.24 \\
\hline Sulphate $\left(\mathrm{SO}_{4}\right)$ & $\mathrm{Mg} / \mathrm{L}$ & 3.04 & 1.23 & 1.78 & 2.31 & 2.66 & 2.204 & 0.6558 & 1.81 \\
\hline Temperature & ${ }^{0} \mathrm{C}$ & 32 & 28 & 27 & 30 & 390 & 31.2 & 4.2615 & 12 \\
\hline $\mathrm{pH}$ & & 6.82 & 6.90 & 7.02 & 7.00 & 7.09 & 6.066 & 0.09499 & 0.27 \\
\hline $\begin{array}{l}\text { Electric } \\
\text { conductivity }\end{array}$ & $\mathrm{Ms} / \mathrm{cm}$ & 21.02 & 14.22 & 12.26 & 8.74 & 16.23 & 14.494 & 4.0933 & 12.28 \\
\hline SAR & & 0.5321 & 0.0232 & 0.0065 & 2.9147 & 0.1324 & 0.7218 & 1.1128 & 2.9082 \\
\hline Sodium \% & & 0.4418 & 0.3154 & 0.0647 & 2.2061 & 0.3429 & 0.6748 & 0.7759 & 2.1414 \\
\hline
\end{tabular}

Source Field and Laboratory Analysis, 2014

$\mathrm{X}=$ Mean, $\mathrm{S}=$ Standard deviation, $\mathrm{R}=$ Range 